The Catholic University of America, Columbus School of Law

CUA Law Scholarship Repository

1993

\title{
Tort Claims in Counterinsurgency Operations: The British Experience in Ireland, 1919-21
}

Michael F. Noone Jr.

The Catholic University of America, Columbus School of Law

Follow this and additional works at: https://scholarship.law.edu/scholar

Part of the Comparative and Foreign Law Commons, Military, War, and Peace Commons, and the Torts Commons

Recommended Citation

Michael F. Noone, Tort Claims in Counterinsurgency Operations: The British Experience in Ireland, 1919-21, 57 J. MIL. HIST. 89 (1993).

This Article is brought to you for free and open access by the Faculty Scholarship at CUA Law Scholarship Repository. It has been accepted for inclusion in Scholarly Articles and Other Contributions by an authorized administrator of CUA Law Scholarship Repository. For more information, please contact edinger@law.edu. 


\section{Tort Glaims in}

\section{Counterinsurgency Operations:}

he British Experience in Ireland, 1919-21

Michael F. Noone, Jr.

Laws are like cobwebs, for if any trifling or powerless thing falls into them, they hold it fast; but if a thing of any size falls into them, it breaks the mesh and escapes.

-Solon, 6th Century B.C.E. ${ }^{1}$ $W_{\text {the fabric of society and that extraordinary measures, including }}^{\text {HEN a government concludes that political violence threatens }}$ the domestic use of the armed forces, are appropriate, it must ensure that the legal system is sufficiently flexible to accommodate these measures. Typically, the authorities are granted enhanced powers to search property and to detain and question suspects. These enhanced powers are subject to abuse, particularly when soldiers inexperienced in police work are called upon to exercise them. If the abuse was intentional-rape, looting, or murder-the soldier or policeman can be prosecuted in the criminal justice system. Should the government pay compensation as well? And what of the victims of innocent mistakewhen, for example, soldiers search the wrong house and damage it in the process? If there are no provisions for compensation for the tort (a legal wrong), the government risks alienating those it claims to protect. If it does establish a claims mechanism, it will be forced to admit that, on occasion, security forces acted improperly, diminishing their morale and the public's trust.

1. Diogenes Laertius, Lives of Eminent Philosophers, R. D. Hicks, trans. (Cambridge, Mass.: Harvard University Press, Loeb Classics, 1980), 1: 1.59. 
The dilemma is particularly acute in Anglo-American law, which does not provide a doctrinal counterpart to the European "state of siege." 2

Under our system, unless martial law has been declared, peacetime legal rules apply and the cobweb of law is unaffected. Moreover, even if martial law has been declared, citizens expect some mechanism for resolving disputes arising from the activities of security forces. In war time-and military historians tend to treat counterinsurgency campaigns as "small wars"-collateral damage to civilians is rarely worthy of comment. However, if the battle is truly for the hearts and minds of the populace, then the military response to such relatively trivial complaints warrants close attention, for it reflects fundamental attitudes toward counterinsurgency policies and tactics. The Anglo-Irish guerrilla war from early 1919 to July 1921, known as "The Troubles," offers an opportunity to examine policies and tactics in an exceptionally welldocumented context, ${ }^{3}$ from the perspective of those charged with maintaining the web of law.

\section{The Political and Legal Background}

The British political presence in Ireland began in May 1169, when Henry II, King of England, responded to a call for assistance from Dermot MacMurrough, King of Leinster, by permitting six hundred of his Norman vassals, settled in Wales, to invade the island and conquer Dermot's Irish and Norse opponents. The Normans and native Irish aristocracy intermarried and formed an Anglo-Irish ruling class which recognized the English monarch as their titular head. After the

2. "The law of most foreign countries recognizes an intermediate state between war and peace, known by the name of the state of siege, under which the ordinary law is suspended for the time being by proclamation, and the country is subordinated in whole or in part to military authority by proclamation, but such a state of things cannot exist under English law, which never pre-supposes the possibility of civil war, and makes no express provision for such contingencies. In short, although in the arbitrary times of our history attempts were made to apply military law to the civil population, such attempts have long been recognized to be illegal. Martial law, in the proper sense of the term, can be established in the United Kingdom or in a self-governing British Possession only by an Act of Parliament or of the local legislature." War Office, Manual of Military Law (London: HMSO, 1914), 3-4 (authorities omitted). The standard American text states that "martial law, in this country, resembles, and has been compared to, the state of siege of the continental nations of Europe-a condition of domestic military rule." W. Winthrop, Military, Law and Precedents, 2d ed. (Washington: GPO, 1920), 818.

3. The documentation is at the Public Records Office, Kew, England, particularly in War Office (WO Group) Records Class 35, and in Treasury (T Group) Records Class 161. Citations to Public Records Office material will give the Group letter(s), Records Class and piece (file or document) numbers. 
formation, Elizabeth I thoroughly conquered the Irish, who sought to iêtmain Catholic, and she and her successor James I encouraged English and Scottish Protestant settlements in the island. During The English Givil War, the Irish supported the Royalist cause of Charles I and guffered accordingly when Cromwell's armies subjugated the country. A mew Protestant landed ruling class of Scottish and English origin was established and survived the collapse of Cromwell's Commonwealth. During the Glorious Revolution of 1688-89, the Irish again supported the losing side and, at the Battle of the Boyne, saw James II's Catholic upporters defeated by William III's Protestant forces.

The eighteenth century was a period of severe repression: Catholics could not own land, have schools, speak their native language, or worship according to their faith. Despite regaining the right to vote in 1793 , they rebelled in 1798 . After the rebellion was crushed, the Irish parliament was abolished and the Act of Union, passed in 1800 , required that all Irish members of the Parliament in Westminster be Protestant. There was an attempted rebellion in 1803 and, although Catholics won the right to serve in Parliament in 1829 , political violence became endemic. Food riots and attacks on landlords were punctuated by a "tithe war" (over taxation) in the $1830 \mathrm{~s}$, a minor rebellion in 1848 , a major uprising in 1867, and a "land war" in the 1880 s (over the system of tenant farming).

Endemic political violence led successive British governments to formulate distinctive security arrangements which applied only in Ireland: a national police force was formed, ${ }^{4}$ and a barrage of legislation gave the authorities in Ireland extraordinary coercive powers over the populace. 5 Violence declined in the period $1890-1910$ as British politicians attempted to deflect the demand for "Home (local Irish) Rule" by passing ameliorating legislation intended to improve the economic and political status of the Catholic majority without affecting Parliament's governance of the island. In 1912, when it became apparent that Home Rule might pass, Ulster (the Northern Province) Protestants began to threaten eivil war. In April 1914, guns for the Ulster Volunteers were landed and in July their Catholic counterparts, the Irish Volunteers, received a similar shipment. However, the confrontation was postponed by events in Europe.

4. The early history of The Peace Preservation Force, which was to become the Royal Irish Constabulary, and its relations with British army units garrisoned in Ireland is described by Galen Broeker in Rural Disorder and Police Reform in Ireland, 1812-36 (London: Routledge \& Kegan Paul, 1970).

5. Charles Townshend's Political Violence In Ireland: Government and Resistance Since 1848 (Oxford: Oxford University Press, 1983) gives a good overview of the period preceding The Troubles. 
In August 1914, Britain declared war on Germany and the Home Rule Bill's effective date was postponed for the duration of the war. By 1916, one hundred and fifty thousand Irishmen, Catholic and Protestant, had voluntarily joined the British forces. In order to remind the Catholic majority of their claim to independence, the Irish Republican Brotherhood staged a "Rising" on Easter Sunday 1916, and proclaimed a Republic. The Rising barely spread beyond the city of Dublin and after a week the rebels surrendered. The rebel leaders were tried by courtmartial and shot. Two years later, in November 1918, the war in Europe ended, and the Protestant ("Loyalist") minority began to agitate against implementation of Home Rule which would give Catholics majority representation. In December 1918, Irish nationalists elected to Parliament refused to take their seats, met in Dublin instead, and in January 1919, demanded the evacuation of British forces. The British refused and two and a half years of guerrilla warfare began, as fifteen thousand members of the Irish Republican Army faced forty-three thousand British troops, the Dublin police force, the Royal Irish Constabulary, reinforced by recruits from England (called "Black and Tans" because of their uniform), and police auxiliaries composed of ex-officers in the British Army. Violence continued until 11 July 1921, when a truce went into effect. During the thirty month period, 555 members of the security forces had been killed, and 1027 had been wounded. Givilian casualties amounted to 196 killed and 185 wounded. ${ }^{6}$ An Anglo-Irish treaty which attempted to partition the island along religious lines was signed in December 1921.

The decision, in 1919 , to rely on troops to aid the civil authorities was consistent with national legal traditions. One of the consequences of The Glorious Revolution of 1688-when Parliament succeeded in ejecting the Stuart monarchs and replacing them with the more compliant reigns of William and Mary and Queen Anne, and after 1714, with the Hanoverian line-is described in a history of the English Army published in 1801:

The revolution, which shortly after succeeded, caused the military part of the constitution to be new modelled, and the army to be voted from year to year only, by an act called the mutiny bill, which is prefaced by a declaratory clause, that it is unlawful to raise or keep a standing army in time of peace, without the permission of parliament. ${ }^{7}$

6. Derived from Charles Townshend, The British Campaign in Ireland, 19191921 (Oxford: Oxford University Press, 1975), Appendix V, 214.

7. Francis Grose, Military Antiquities Respecting a History of the English Army from the Conquest to the Present Time (London: T. Egerton \& G. Kearsley) 1801), 1: 64. Spelling has been modernized. 
Ment thus ensured that they would exercise some control over the irganized force capable of interfering with parliamentary democ-

通owever, it must be emphasized that parliaments of the eighteenth il ineteenth centuries were not averse to the use of military force, if within the British Isles. Relatively large bodies of troops were ilsoned in Ireland and Scotland to suppress demonstrations of popular (i)ntent. In this regard British practice followed a continental model, in routinely used troops for this purpose, quite different from that of United States where the Second Amendment of the Bill of Rights Sintended to protect citizens and the states from armed intervention the central government. 8 Thus, when the British were faced with sturbances in Ireland in 1919, there were no constitutional restraints ded duding use of the Army. Moreover, the British legal system had adde several accommodations to the peculiar legal problems raised by Gimestic political violence. Parliament could, and did, statutorily ispend the right to seek habeas corpus, usually for no more than a few 酳onths. 9 Parliament might suspend the right to a jury trial in "disturbed" peas ${ }^{10}$ or subject civilians to trial by court-martial. ${ }^{11}$ Martial law might imposed by statute or proclamation even if the courts were (0)perating. ${ }^{12}$

Although civil rights could be severely curtailed, the Common (customary) Law provided some redress from government excess by Nllowing the eitizen to sue Crown officials for any legal wrong. The

8. Allan R. Millett, The American Political System and Civilian Control of the Gilitary: A Historical Perspective (Columbus: The Mershon Center of the Ohio tate University, 1979), 8. The U.S. Army's Center of Military History projects several volumes on the use of federal military forces in domestic disorders. One has iseen published: R. W. Coakley, The Role of Federal Military Forces in Domestic Disorders, 1789-1878 (Washington: GPO, 1988).

9. See, e.g. Broeker, Rural Disorder, 134-35, for a discussion of one such act passed in 1822.

10. See, e.g. 54 Geo. III c. 180 (Insurrection Act of 1814).

11. See, e.g. 3 \& 4 Will. IV, c. 4 (Suppression of Local Disturbances Act of 1833). The rationale for such trials was that men who had taken up arms against the Crown were soldiers. Under English law, soldiers could be prosecuted for any crime committed in war time. Rebellion constituted incipient war, ergo rebels could be subject to court-martial. W. F. Finlason, Review of the Authorities As to the Repression of Riot or Rebellion (London: Stevens \& Sons, 1868), 63-79.

12. W. S. Holdsworth, "Martial Law Historically Considered," Law Quarterly Review 18 (April 1902): 117-32; K. O. Fox, "Public Order: The Law and the Military," Army Quarterly and Defense Journal 104 (April 1974): 295-307; S. H. Palmer, "Calling out the Troops: The Military, the Law and Public Order in England, 1650-1850," Journal of the Society for Army Historical Research 56(Winter 1978): 198-214; L. Radzinowicz, A History of English Criminal Law and its Administration from 1750, IV (London: Stevens and Sons, 1968). 
official's liability would be determined by normal (peacetime) tort law. The victim would have to establish that the official was at fault, either through carelessness (failing to foresee the risk of his acts and taking reasonable precautions) or intention (acting with the desire or knowledge that the victim would be harmed). The Common Law doctrine of sovereign immunity precluded a tort suit against the Crown on the rationale that if the Crown had authorized the action, it could not be a wrong. 13

The Common Law permitted damage suits against Crown servants, if they exceeded their authority, even though they were acting in good faith. For example, in the case of Huckle v. Money (1763), ${ }^{14}$ a justice of the peace was held liable for false imprisonment and subjected to punitive damages when he complied with an arrest warrant which, the court ruled, he should have known was invalid. Soldiers learned that a praiseworthy motive would not relieve them of liability if they harmed innocent civilians. The [British] Manual of Military Law gives an example of the civil consequences:

In Glynn v. Houston Mr. Glynn, A British merchant residing in Gibraltar recovered £50 damages from General Sir William Houston, the acting Governor, for having caused Mr. Glynn's premises to be surrounded with a detachment of troops, while a house immediately adjoining was searched for the person of Torrijos, a Spanish general; and for having during the search (which was unsuccessful) prevented Mr. Glynn from leaving his house by placing a sentinel with a fixed bayonet at his door. ${ }^{15}$

The criminal consequences were, from the standpoint of the Army, similarly discouraging. Soldiers, like civilians, were permitted to use deadly force only if necessary, but necessity was determined by a civil jury after the fact. Officers and men who had fired on civilians were prosecuted in eivil courts and sometimes convicted. ${ }^{16}$ Because the Common Law's protection of security forces was, in the government's view, inadequate, it had been parliamentary practice since Cromwell's time to pass Indemnity Acts, at the conclusion of a declaration of martial law, to protect Crown servants from liability by prohibiting suits

13. H. Street, Governmental Liability (Cambridge: Cambridge University Press, 1953) 1-3.

14. (1763) 2 Wilks. K.B., 95 Eng. Rep. 768.

15. Manual of Military Law, 132. The case is reported at 133 Eng. Rep. 775 (1841 C. P.).

16. The literature on these incidents is extensive. Accessible summaries are found in W. Nippel, "Reading the Riot Act: The Discourse of Law Enforcement in 18th Century England," History and Anthropology 1 (1985): 401-26, and Radzin. owiez, History of English Criminal Law, IV, c. 4. 
Winst them for acts done in good faith during the emergency. ${ }^{17}$ Thus, the innocent person who suffered injury or loss during security Fations was not well protected by the Common Law which required idie(or her) to identify the person who had caused the injury and to 蕃blish that the individual was at fault. If the claimant were successful, suit might still fail if Parliament decided-after the fact-to pass a tate of indemnity. There were, however, two alternative sources of ingensation, one statutory and the other based on the curious English grincept of the Royal Prerogative.

Because the Common Law required that the assailant be named in law suit, the legislature devised a statutory alternative to protect iftims who had suffered property damage caused by criminal activity W.mmitted by unknown persons. This legislation, which had its origins a parliamentary act of 1285,18 had by the time of The Troubles olved into the Local Government (Ireland) Act 1898 which provided ingat a civil court could hold the local county council, a municipal Trporation, legally liable upon proof of damage or loss to property tionaliciously injured or destroyed. In effect, the Act served as a locally onded government insurance program, primarily protecting those Whose property would be destroyed by riots or by agrarian crime, e.g., tillie mutilation of cattle or arson, both commonly directed toward Winglish and Anglo-Irish landlords. ${ }^{19}$

Acts of the security forces could not usually be the basis for a suit Sainst the county, unless the claimant could establish that individuals fad acted maliciously, or without authority. If the security forces had

17. "In the Civil War, strange as it may seem to be, the Parliamentary officers and soldiers seem to have been troubled with actions and indictments in the civil ard criminal courts. Application was made to Parliament and an ordinance in 1647 was passed for their relief." Charles M. Clode, The Military Forces of the Grown (London: John Murray, 1869) 1, 10. Subsequently Indemnity Acts were Fassed after the Glorious Revolution, 4 W. \& M., c. 19, after the Scottish rebellion of $1745,19 \mathrm{Geo}$. II, c. 20 and c. 29 , sec. 18 , and the Irish rebellion of $1798,41 \mathrm{Geo}$. III, c. 104. Clode also reports that when soldiers in Scotland and Ireland were findicted for homicides which occurred during the suppression of violence, the Gituart kings instructed Crown Law Officers to refuse to prosecute. Ibid., 2: 615-16. Iindemnity acts are discussed in W. F. Finlason, Review of the Authorities, 88-95, and criticized in C. Townshend, "Marital Law: Legal and Administrative Problems in Britain and the Empire, 1800-1940," The Historical Journal 25 (March 1982): $167-95$ at 176 .

18. The development of the principle of government compensation for criminal acts is traced in Desmond Greer and Valerie Mitchell, Compensation for Criminal Bamage to Property (Belfast: SLS Legal Publications, 1982), 1-16 (covering the period up to 1919).

19. However, compensation for damage to property in Dublin during Easter Yeek 1916 was handled under a system established solely for that purpose. Ibid., 15 n. 4. 
been acting under proper authority, a suit could not be brought and the claimant's only recourse was to ask the Grown to exercise the Royal Prerogative by making an ex gratia payment from public funds. ${ }^{20}$ Because such payments were matters of grace, within the sole discretion of the executive, there were no legal criteria describing how and when they might be made. Government guidelines were not published until 1970, but it was this obscure and unpublicized compensation system on which English and Irish claimants against the security forces would be obliged to rely during The Troubles.

\section{The Claims: 1919-21}

Requests for ex gratia payment offer a unique perspective of the kinds of problems that arise during a counterinsurgency campaign. Operations go awry. The military claims to be able to distinguish friendly from unfriendly civilians, and has little sympathy for neutrals. Efforts to treat the population evenhandedly deteriorate as the conflict continues and, lacking policy guidance, authorities resort to ad hoc decisions which disaffect supporters. Because the problems and their solutions arose in the context of tactical situations, they have, for analytical purposes, been placed in three categories: those claims arising from searches (called "raids" by the British); those arising from retaliatory actions; and those miscellaneous claims attributed to actions of the Army.

Claims arising from raids were the most common. Security forces might search private property for a variety of reasons: to seize contra. band; in search of suspects; or to gain information about Republican plans, membership, and organization. Various statutes and regulations permitted searches without the necessity for a warrant. Typically, the property to be searched was surrounded by a detachment of soldiers, usually twelve to twenty men. ${ }^{21}$ If it was a residence, a member of the unit would knock three times on the front door but, if the door were not opened promptly (and it often was not because most searches were in the middle of the night), the door was breached. ${ }^{22}$ If the property was not a residence, entry would be forced. Army authorities received numerous claims for the replacement of broken locks, windows, and

20. Payments had been made as early as the mid-eighteenth century, Cobbet's Parliamentary History (London: T. Hansard, 1749), 14:497-538 (debate on grant of compensation for the eity of Glasgow after the 1745 rebellion).

21. Townshend, British Campaign, 128.

22. See, e.g. WO 35164 , file 846/699/A (wrong house raided; several doors and windows broken to gain entry because claimant's wife, who was home alone, refused to open the door in the middle of the night). 
The applicable Common Law principles dictated that any claim thespass to property should be denied on the grounds that the acts re justified by apparent necessity ${ }^{23}$ and by the fact that the damage tone in connection with the execution of legal process. If the iring house was searched, but the mistake was reasonable under the if tactor. If compensation were to be paid, it would only be as an act of gee.

In those few cases where contraband was found, it is not surprising ataims for ex gratia compensation were rejected ${ }^{25}$ even if there was fovidence that the claimant was implicated. Although officials were lifially willing to compensate innocent landlords, ${ }^{26}$ subsequently, the iticy changed. ${ }^{27}$ If contraband had been found once, damage caused subsequent unsuceessful searches was not compensable. ${ }^{28}$ In cases he contraband was found, claims policy changed over time. At

23. Malevererv. Spinke (1538), 1 Dyer 35b, 73 Eng. Rep. 79; King's Prerogative Salpetre (1607), 12 Co. Rep. 12, 77 Eng. Rep. 1294.

24. See, e.g. W0 35169 , file 24/395/23 (lieutenant given two hours to prepare raid a house in a residential district at the other end of Dublin; he made a diminary reconnaissance, returned, organized the raiding party, returned with igm to the neighborhood and broke into the house only to learn that the address thad been given was of a house across the street. He said that, had he been given ingre time, he could have checked the house numbers more carefully. His superiors 感eed that it was an unfortunate accident).

25. WO 35165 , file $876 / 262 /$ A (claim for broken door lock and dresser drawer nide denied because a Republican pamphlet and round of ammunition were found); ijad., file 846/659/A (book store owner's claim for broken locks and window, iivure of two books, missing watch and the contents of a cash box rejected, 的arently on the grounds that one of the books, published by a well-known English iullisher, was pro-Republican).

26. See e.g. WO 35165 , file $6 / 89 / 3$ (arms and ammunition found in a tenant's airtment; telephone, property of the landlord, seized and compensation recom(nded).

27. See e.g. WO 35169 , file 33/50l/16 (bomb-making equipment found in 12013iles; lessors' claim for broken door and windows rejected); WO 35165 , file 460/43 (Loyalist landlord's claim for broken lock rejected because contraband as found in a tenant's apartment). WO 35165 , file $31 / 460 / 19$, contains the earest statement of policy: "The view taken by me is that the owner of the nestises is responsible for any act of his tenant, and the War Department is ponsible to the landlord, only if he is in occupation of his premises. The tenant Jis known to be a bad character, and is now a convicted prisoner... I consider Hefrefore that the landlord should suffer the loss'owing to the class of tenant he let 3remises to." Ltr., C. O. Dublin District to GHQ, 21/9/1921. Ultimately, Army iifithorities directed that if the premises had been used for illegal purposes, claims infuld be repudiated without investigation. WO 35 168, file 876/300/R (Ltr. 23 21 from Chief, Lands Office, GHQ to Dublin Distriet).

28. Wo 35165 , file $33 / 501 / 9$. 
first, property damage claims were paid routinely, ${ }^{29}$ but, as the number of claims increased, they were either rejected on the grounds that the damage was unavoidable $e^{30}$ or simply held in abeyance, pending guidance from the War Office and Treasury. ${ }^{31}$ The amounts claimed were relatively small, ${ }^{32}$ however, and claimants had no alternative but to wait patiently for compensation.

Efforts to set criteria for the payment of meritorious claims foundered over two fundamental policy questions which had not been considered before the campaign began: who should bear the cost of damage caused by an unsuccessful raid, and whether the claimant's loyalty to the regime should be taken into consideration. The first question was referred to the War Office and Treasury in September $1920^{33}$ and remained unresolved throughout The Troubles. The question of loyalty was more easily, if not satisfactorily, resolved by the Army.

Searches were usually based on information received. Although in some cases, the "information" was exiguous, ${ }^{34}$ in most the claimant had been identified as a Republican sympathizer. Standard tort doctrine dictates that the political sympathies of a tort claimant are irrelevant. However, elaims for compensation ${ }^{35}$ submitted by Republican sympa-

29. See e.g. WO 35165 , file $6 / 89 / 16$ (claimant, a known member of the Republican ["Sinn Fein"] party who was arrested and subsequently released, was paid for his broken door).

30. See e.g. WO 35169 , file 25/354/7 (sergeant inspected the premises, made a settlement offer which was accepted but his offer to pay for a broken door and missing cash box was subsequently repudiated).

31. WO 35165 , file $846 / 6 / Q$ exemplifies the way later cases were handled. On the night of 12 May 1921, the security forces broke down the door of a residence at 37 Fitzwilliam Place in Dublin because the residents did not open the door promptly. After the search, the residents, a major serving with the British forces in Ireland and his wife, were told that the forces had made a mistake and should have searched 37 Upper Fitzwilliam Street. The major submitted a claim for damage to the door in July; the claim was denied in September. His commander then intervened and was told that the claim would be reconsidered. The final entry in the file is a letter to the commander in January 1922, advising him that no final decision had been made.

32. E.g. WO 35 164, file 31/460/45 (jug and basin accidentally broken during a raid).

33. T/161/62/S.442.

34. For example, WO 35 168, file 6/89/46, where a raid in Dublin was made on the basis of an address and partial name found during a search in Cork, 150 miles south of Dublin.

35. A few claims involved requests for the return of property. In those cases, it the property was not contraband, it was returned. WO 35165 , file $6 / 89 / 25$ (seamstress's woolen yardage, seized as "army blankets" when her husband was arrested as an IRA member, retumed as "an act of grace"); ibid., file 6/89/4 (machine used to make badges carrying the photographs of Republican leaders returned to owner). Contraband could be broadly defined as in WO 35164 , file $30 / 459 / 45$ (uniform of a demobilized soldier retained as military impedimenta). 
zers were summarily rejected on policy grounds. ${ }^{36}$ Landlords were Id responsible for the behavior of their tenants, and organizations for illitical activities of their members. ${ }^{37}$ Loyalty was determined by the iselligence branch and claims adjudicators were in no position to allenge a determination that the claimant was a sympathizer or Sloyal even though "[ in a raid or search situation] the problem of stinguishing wanted men from innocent eivilians proved almost isuperable." 38 The Army claimed to be able to make the distinction, Wich came to be particularly significant in cases involving the alleged heft of property during the course of a search.

A number of allegations of theft, usually of currency kept in the guse, were made. They became so common that leaders of raiding "intries were instructed to check the contents of soldiers' pockets before and after the search. ${ }^{39}$ A special form was devised in the Dublin area, Guiring the raid commander to ask residents if anything had been 解ken and to sign their name to a form acknowledging that nothing was inissing. ${ }^{40}$ While the form may have had some prophylactic effect, inany claimants simply said that they were unaware of the loss until ofither the soldiers had left. ${ }^{41}$ Early in the campaign an officer reported:

36. WO 35164 , file $846 / 699 / \mathrm{A}$ (house raided in error and several locks sisoken).

37. The most notorious of these cases involved raids on five Dublin law offices. in each case, a solicitor in the office had been involved in suspect activity: two had erved as judges in civil suits brought in the alternative Republican court system; Whother was being tried for the possession of prohibited literature; another was the Pitficial typist for the Republican Parliament, and the last had spoken for independ. Since. WO 35168 , Secret letter from Dublin C.O. file 876/24.4.1921 to GHQ. The diaims, for business losses and property damage, were originally rejected because of (he Republican affiliations of the firm's members but were subsequently reconsidered payment of the property damage, apparently in response to protests from the itgal profession. WO 35165 , file $876 / 9 / Q$ P.

38. Townshend, British Campaign, 125.

39. WO 35165 , file 31/460/12 contains a Secret "pro forma" report to be used on raids, which includes a certification that the raiding party was searched on aeturn to barracks and that nothing of value was found.

40. These procedures are exemplified in WO 35166 , files $6 / 89 / 10$, and $6 / 89 / 17$. 41. Five files from WO 35169 illustrate elaims for theft which allegedly took hace during raids: $846 / 644 / \mathrm{A}$ (claim for missing gold wateh and fountain pen genied because claim could not be substantiated); 31/460/4 (claim for missing (Nurse and money denied because no complaint made before troops departed); 169/34 (claim for a missing raincoat denied because the claimant had "literature of a most treasonable description" in the house); 846/694/A (claim for missing Furse and money denied because a search of the raiding party failed to find the indissing items and members of the household were all Republicans). Not all claims me unsubstantiated. WO 35165 , file $846 / 642 /$ A reports a stolen purse found after search of the raiding party. 
"all these cases are carefully investigated and there is great difficulty in dealing fairly with them. In the case of proven loyal subjects, such as [the claimant] apparently is, although I do not admit that an officer and the sergeants would, under any circumstances, have touched anything of the kind mentioned, I recommend [payment of the claim]." 42 However, if the claimant had Republican affiliations, the authorities were inclined to treat the claim as baseless.

Looting by security forces in areas where the residents were considered to be inclined to Republicanism was also a problem, particularly when it occurred as the aftermath of an attack on the Army or police. ${ }^{43}$ Allegations of looting and theft were taken seriously and investigated by the authorities. In some cases, there was sufficient proof to warrant court-martial, 44 but there do not seem to have been any cases where a claim was paid. Damage or loss in such cases was treated as "unofficial" and thus not within the purview of the ex gratia compensation system. ${ }^{45}$ Clearly there were overriding considerations: any liberality by the government would be seen as a public admission of indiscipline and as a blow to the morale of the troops involved. Army authorities claimed that they were not morally responsible for the theft, ${ }^{46}$ and the courts ruled that theft was not a basis for bringing suit against the local authorities ${ }^{47}$ unless it was the natural and direct consequence of a riot where malicious damage occurred. 48

A few claims were submitted for the lost use of property seized by the authorities and subsequently returned. In most cases, although the claimant could show that the seizure was unreasonable, claims for economic loss were rejected. 49

42. WO 35164 , file $24 / 395 / 22$.

43. WO 35165 , file $846 / 225 / \mathrm{A}$ (soldiers looting Republican shops in Dublin in retaliation for stone throwing); PRO 35164 , file 4/10 (liquor and food stolen by police auxiliaries who then burned the shop).

44. WO 35165 , file 31/460/6 (officer and sergeant acquitted of charges of looting, elaiming that the house had already been burglarized when they entered it). WO 35164 , file $846 / 648$ /A (theft claim rejected after court-martial conviction quashed because ownership of property not established). See also WO 35165 , file $846 / 12 / Q$ (court-martial sentences of six months' confinement for looting commuted to 90 days).

45. WO 35165 , files $25 / 354 / 1$ and $33 / 501 / 33$.

46. $\mathrm{T} / 161 / 62 / \mathrm{S} .442 /$, file $2388880 / 16$ (property taken from well known Repub: lican sympathizer).

47. Leyburn v. Armagh C.C. (No2) [1922] 2 I.R. 58.

48. Tyler \& Sons Ltd. v. Cork C.C. [1921] 2 I.R. 8.

49. WO 35165 , file $3 / 460 / 67$ (rubber stamps in Gaelic returned after their tex was determined to be nonpolitical, but printer's claim for lost revenue rejected) WO 35168 , file 6/89/141 (car seized by security forces looking for contraband and dismantled; none was found. No compensation for five-month delay in returning 
laims arising from reprisals created a second category of problems inge authorities. "Reprisal," the forcible taking by one nation of the terty of another in satisfaction for an injury committed by the latter We former, had long been recognized as an accepted doctrine in fotional law, particularly in the law of armed conflict. The British intulal of Military Law gave two rationales for reprisals:

punish persons who had violated the law of war:

The custom of war permits as an act of reprisal the destruction of a house, by burning or otherwise, whose inmates, without possessing the rights of combatants, have fired on the troops. Care, however, must be taken to limit the destruction to the property of the guilty. ${ }^{50}$

-ror to coerce cooperation:

Reprisals are an extreme measure because in most cases they infliet suffering upon innocent individuals. In this, however, their coercive force exists, and they are indispensable as a last resort. . . Although collective punishment of the population is forbidden for the acts of individuals for which it cannot be regarded as collectively responsible, it may be necessary to resort to reprisals against a locality or community for some act committed by its inhabitants, or members who eannot be identified. ${ }^{51}$

Of course, the law of war did not apply in cases of domestic political lence, but among the examples given was that of reprisals threatened the British commander during the Boer War after martial law had proclaimed. ${ }^{52}$ Moreover, a standard British military text of the inod obvserved: "The French in Algeria, regardless of the maxim, 'Les 'orésailles sont toujours inutiles,' dealt severely with the smoldering is affection ... and their procedure succeeded." 53

The first reprisals by British forces in Ireland were undertaken Bout authority ${ }^{54}$ and, as such, would not be the basis for ex gratia gims. If the claimant were to be compensated, he would have to be ile to identify the soldiers responsible and sue them as private dividuals or establish that a riot had occurred. However, in the last it

WO 35165 , file 876/9/Q (no compensation for disturbance and loss of औipess, loss of tenant's rent and cost of reduplicating seized correspondence ien solicitors' office raided).

50. Manual of Military Law, 296-97.

51. Ibid., 304-5, citing Article 50 of the Regulations Respecting the Laws of ind Warfare annexed to The Hague Conventions, 1907.

52. lbid. 305 n.(b).

53. C. E. Callwell, Small Wars: Their Principles and Practice (London: HMSO, 99), 118.

54. Townshend, British Campaign, 95-96. 
week of December 1920, British troops in specified areas were authorized to respond to Republican attacks by destroying the homes of selected members of the civilian community according to the following rules:

A. Punishments will only be carried out on the authority of the Infantry Brigadier, who, before taking action, will satisfy himself that the people concerned were, owing to their proximity to the outrage or their known political tendencies, implicated in the outrage, and will give specific instructions in writing or by telegram to the officer detailed to carry out the operation.

B. The punishment will be carried out as a Military Operation, and the reason why it is being done will be publicly proclaimed. ${ }^{55}$

These apparently straightforward instructions were to give rise to a number of troublesome questions. ${ }^{56}$

When an "implicated" person was a tenant, should the landlord be compensated for the destruction of the house? Some commanders believed that only owner-occupied homes were subject to destruction ${ }^{57}$ while others believed that the owner of a house should be responsible for his tenants. ${ }^{58}$ Confronted with the dilemma, an official in the General Headquarters eventually advised subordinate commanders confronted with such claims to "play for time." 59 Meanwhile, landlords (typically loyal to the regime and often English) and the Loyalist press eriticized the government's refusal to honor the claims. ${ }^{60}$

When the wrong house is destroyed, should the owner be com. pensated? While it might be (militarily) logical to conclude that landlords were vicariously responsible for the political beliefs of their tenants, that logic could not be extended to property owners whose houses were destroyed in error because the security forces were misinformed as to the ownership of the property. ${ }^{61}$ The authorities were never able to

55. Ibid., 149, quoting from General Officer Commanding, Weekly Situation Report, 1. January 1921.

56. Unless otherwise indicated, all the incidents in this category are found as. subfiles in WO 35 169, File 79/Irish/753 (Claims Arising out of Official Reprisals in Ireland).

57. Sub file 36/549/6, Ltr. HQ 16th Inf. to O.C. Troops Waterford, 19.6.21.

58. "If loyal people let their houses to disloyal people, I consider they do so at their risk." Ltr. 6 Div. Hq, to GHQ Dublin, 13.7.21, ibid.; see also sub file 36/549/8, Ltr. Gdr. 16th Inf. Brigade, Fermoy to HQ 6th Div. Cork expressing the same sentiment while forwarding solicitor's claim on behalf of minor.

59. "The Chief Crown Solicitor was asked for advice and he advises [delay]. We are in a position of difficulty in such cases. ... I was hoping we would have had an Act of Indemnity last Session of Parliament but I expect that there will be one nex? session. Meantime we must play for time." WO 35169 Sub file 36/549/20, Ltr, 2/46210/33 Q, 3.1.22 to HQ 6th Div.

60. Townshend, British Campaign, 150.

61. The claim in sub file $36 / 549 / 6$ is representative: two houses had been 
how such claims should be handled and, treating them like the sof absentee owners, held them in abeyance. ${ }^{62}$

fas a consequence of reprisal, collateral damage is suffered by ent landowners, should they be compensated? Units were told to he objects of reprisal an hour to remove food (but not furniture) ij the house which was then burned or destroyed by explosives. In 艟 areas, where there was a threat that fire might spread, the ifure was removed and burned in the street. ${ }^{63}$ Although precautions giken to avoid damage to neighboring houses, ${ }^{64}$ damage occurred. claims were routinely rejected on the grounds that the damage inavoidable, ${ }^{65}$ although army commanders recommended ex gratia miment in the cases of known Loyalists, ${ }^{66}$ the relatives of members of armed forces, ${ }^{67}$ or where the claim was submitted by public orities. ${ }^{68}$ Conversely, claims by persons related to Republican in pathizers were rejected, ${ }^{69}$ as were claims submitted by landlords

Soyed because they were mistakenly thought to be owned by the sister of a 䅦解lican fugitive.

6. In a particularly egregious case, the authorities destroyed a house under the ighaken belief that it was owned by a Republican sympathizer, when it was in fact of of an estate held in trust for three young children. Both the Brigade and Wision Commanders recommended payment. The War Office responded that so of culpable negligence were a matter for the courts, i.e. the personal liability the soldiers involved, while all other cases were to be dealt with "under the fitheoming Bill of Indemnity." The chief legal officer stated: "I am opposed to initting any mistake [and] do not recommend payment. It would only be argued ait if we admit one mistake there must be others. And in the end they would all be "takes." Sub files 35/5491/9 and 2/46210/30 (L).

63. Townshend, British Campaign, 149.

64. Sub file $42 / 668 / 4$ (neighbors were given time to open windows to minimize blast effects, to remove articles liable to fall, and to paste paper over shop indows.).

65. See, e.g. sub file $36 / 549 / 22$ (house, adjacent to stables which were blown severely damaged); sub file $42 / 669 / 19$ (carriage stored by elderly woman at lifionse destroyed by security forces).

66. E.g. sub file 36/549/12.

67. Sub file $42 / 686 / 6$ (wife of a soldier).

68. Sub file $2 / 462 / 10 / 32$ (school's windows broken when house sixty feet away as blown up ); 36/549/7 (county claim for repair of asphalt and curb after inniture taken from house and burned in the street).

69. One woman's claim was rejected because she was the wife of an individual eported to be one of the most dangerous men in the area." Ltr. Cdr. 6th Div. 30.11.1921 to GHQ Ireland. The difficulty in using loyalty as a litmus test is oflustrated in an RIC Report of 25.7.21 regarding the claim of a boarding house Wher whose house was blown up in retaliation for the wounding of a sergeant and wite murder of a corporal. Her house had been selected because her five boarders tere notorious Republicans. Her son had been a soldier in the British Army killed in 
whose tenants' loyalty was suspect. ${ }^{70}$ The politically neutral claimant whose property was damaged by firemen attempting to put out a blaze which had spread from a neighboring street, where a public house had been blown up by security forces, was simply told that "guidance had been sought" regarding payment. ${ }^{71}$

As the military "played for time," a third category of miscellaneous problems began to accumulate. Tort law, based on the concept of fault, demands proof of causation. Even a liberal compensation scheme would require the claimant to establish that damage had not only occurred, but was due to the acts of the Army. A commander's Solomonic evaluation of the claim for a broken door, submitted by a Dublin Y.M.C.A., illustrates the practical problems both the claimant and the government faced. After reporting that a major military operation had taken place that night, the commander said: "It is quite possible that the premises were entered, but as the party that did so cannot be traced, it is impossible to state if the damage was committed. Under the circumstances, I recommend that half the estimate be paid." 72 In several cases, the authorities concluded that members of the Irish Republican Army wearing British uniforms had looted or destroyed property. ${ }^{73}$ Even where causation was clear, the claim would be rejected if the claimant's loyalty was suspect or the Army's sense of rough justice was offended. ${ }^{74}$

action during World War I; her daughter was married to a sailor in the Royal Navy. The claim was forwarded to higher headquarters without a recommendation. 79 / Irish $/ 753$.

70. The claim of an elderly woman whose house was destroyed by fire that spread from an adjacent house which had been blown up is representative. The police said that she was loyal but that her tenant was "sympathetic to Sinn Fein, to have been a District Nurse during the time operations were in progress and to have lectured on 1st Aid. [The owner] appears to be in quite comfortable circumstances. I do not recommend compensation be given." Ltr. OIC Troops, Tralee, 25.9.21 to HQ Kerry Brigade. Ibid.

71. Sub file 2/462/0118, Memo, HQ 6th Div, 8.12.21.

72. WO 35165 , file $30 / 459 / 28$. Compare WO 35169 , file $36 / 549 / 21$ (claim rejected because no troops were known to have been in the area).

73. WO 35165 , file $31 / 460 / 16$ (looting during a raid); WO 35169 , file $42 / 668 / 1 \& 2$ (destruction of a house from which aid to the poor had been dispensed).

74. In May 1921, while the Coast Guard was practicing rocket signalling, rocket fell on farmland and the fire destroyed a hundred acres of crops. Forwarding the claim, the local commander noted: "The family is undoubtedly Sinn Fein. The son [named] is well known by the Intelligence officer [unit] as a bad lot. The [name] house has been regularly used for the purpose of holding Sinn Fein meetings. . . . [The family] is fairly well off, has made a decent bit of money out of the troops and is generally well protected, for the damage will be paid for from White Cross or other funds if the government does not pay." WO 35 169, fils $42 / 668 / 7$. 
(illaimants had to establish that the individuals who caused damage Sacting with authority. Because Army authorities would only accept hatia claims which involved troops acting officially, claimants who the victims of unauthorized raids, ${ }^{75}$ or of soldiers who had exceeded itauthority, were told to seek compensation through the civil courts, iduse the government was not morally responsible for their acts. "Combat damage" claims were treated as though the incident furred in a war zone. Thus, any claims which arose from an exchange

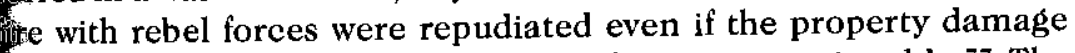
$\operatorname{minor}^{76}$ and the decision to return fire was questionable. ${ }^{77}$ The mat damage" rationale was given its most extreme interpretation ingay through the campaign when, on 17 November 1920, a Royal 然g Corps plane dropping mail to a village struck a radio antenna. ieglane crew was killed and two buildings were severely damaged. A whe filion on the file observes: "We could fairly have said that the Fage in the first instance was in the nature of a fait de guerre as it fonly owing to Sinn Fein activities that the aeroplane was ever used "hail carrying." 78 One wonders whether the same rationale would been relied on had any of the villagers been killed or injured.

War Office records are strangely silent on the subject of personal Winfy and death allegedly caused by the Army. Soon after the campaign 解, coroners were instructed that inquests involving political violence the security forces would be handled by military courts of inquiry. ${ }^{79}$ Isequently, the Army's General Headquarters issued instructions thing the courts which contained the following provision:

When it is likely that in the course of proceedings allegations will be made against members of the Crown Forces, an officer shall be present to represent the Force concerned. The officer ... should, at the discretion of the President, be permitted to put questions to witnesses through the President, and to call 1. evidence. ${ }^{80}$

3

5. See e.g. WO 35165 , file 31/460/6 (lieutenant and sergeant court-martialed (liototing).

76. WO 35164 , file $875 / 616 /$ A (sentry fired on civilians who ran away after 通g been challenged; the shot broke a plate glass window); WO 35168 , file $325 / 25$ (volley fired by troops in response to a sniper's shot damaged YMCA's aige and roof).

77 . Wo 35.165 , file 31/460/20. (Police suspected that shots had been fired at in so troops responded. "In view of the report of the officer $\mathrm{i} / \mathrm{c}$ raid, the military

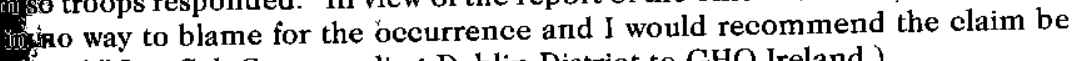
iffigated." Ltr. Col. Commanding Dublin District to GHQ Ireland.)

被, $\mathrm{T} / 161 / 128 / \mathrm{S} 10515$.

790 WO $180 \mathrm{~A}$.

(y) $35147 \mathrm{~A}$, para. 15 of Instructions Relating to Courts of Inquiry held in 触Inquests, 17 December 1920. 
Although several hundred courts of inquiry were held, ${ }^{81}$ only two claims files-one of which was incomplete-were found. In one, the claimant was working by the side of a road when he was shot without apparent reason by someone in an Army truck convoy which was passing. The file was forwarded to Dublin without recommendation and there is no evidence of what action was taken on the claim. ${ }^{82}$ In the other, the family of a sixteen year old male claimed that his death had been caused by security forces. The claim was rejected in light of the Court of Inquiry's findings which were not included in the claim file. ${ }^{83}$ We can surmise that no personal injury and death claims would be paid: either the Army would rule that the soldier was acting without authority or, if the act was authorized, that the soldier was not at fault under the circumstances.

Confiscation claims initially received more favorable treatment. At the beginning of the campaign, the Army believed that it could seize property if any of the following conditions applied: when the property was contraband; when made under the Defence of the Realm Act which permitted war time takings but provided for compensation of the owners; ${ }^{84}$ or when the Army could rely on the prerogative powers of the Crown and seize the property without compensation. 85 If confiscated articles were subsequently lost or destroyed, the Army was willing to pay for damage caused ${ }^{86}$ and did so on at least one occasion. ${ }^{87}$ However, when the War Office sought confirmation of its practices from the Treasury Department in October 1920, a year after the campaign had begun, the Treasury took a far more restrictive view of what claims should be paid.

\section{Disposition of the Claims}

When The Troubles began, there were legal rules available to determine governmental responsibility, but these rules assumed that claims would fall into two categories: those rare cases which involve

81. Records groups WO $35180 \mathrm{~A}$.

82. T/160/140/F 5173 .

83. WO 35168 , file $876 / 230 /$ A.

84. Peter Rowe, Defence: The Legal Implications (London: Brassey's, 1987), contains a brief discussion of the act and its implementing regulations.

85. In 1920 the House of Lords ruled that, where a statutory right to compensatiof for the seizure of real property had been granted in the Defence of the Realm Ad the Prerogative could not be exercised. Attorney-General v. De Keyser's Roy Hotel [1920] A.C. 508 [H.L.].

86. T/161/62/S.442, War Dept. Ltr. 11 Oct 20, 79/Irish/695 (F.3).

87. WO 35169 , file $42 / 668 / 11$ (compensation for buckets, shovels, and piok commandeered and returned damaged). 
âmage claims against the government and could be paid ex (in such cases individual members of the Armed Forces would be (t) by an Indemnity Act); and those claims which were based on ifiorized acts of the security forces which would be handled by the outurt system. The Army soon discovered that valid claims might be ted by disloyal citizens, and that turning soldiers over to a court ldominated by Republican juries would have an adverse effect on te. While there is no evidence of policy guidance from General ingurters to subordinate units, the tone of the correspondence ifding claims changed radically as the campaign continued: from generosity to one which assumed that only the claims of proven sts should be paid. The Army "played for time" while awaiting guidelines from the Treasury.

Ili May 1921, after two years of violence, and only two months if the truce which led to the creation of the Irish Free State, the istry Department at last responded:

"with few exceptions the policy of "no payment" is to be followed.... [No] liability for malicious or felonious Acts of Crown employees will be admitted. In proven instances of culpable negligence or where, for some exceptional reason, you consider some concession politic, full particulars of the case may be submitted in writing direct to the Treasury, [at] Dublin Castle subject to the following procedure. It will there be reviewed by the Quarter Master General [if personal property damage was elaimed], the Adjutant General [if personal injury or death was claimed], and the Chief Lands Officer [who in peacetime handled claims for compensation caused by training activities]. If the Lands Officer recommends payment, and that is concurred in by the local auditor, the case will be forwarded to the Treasury, Dublin Castle, where the Assistant Under Secretary for Ireland, the Chief Crown Solicitor, the Chief Lands Officer and the Local Auditor will consider the case as a board before a report is sent to the Military Authorities.

In applying this procedure... the following considerations may be carefully borne in mind: ... the number of cases to be treated as exceptional should be relatively small and submission to the Treasury should be resorted to after very careful consideration in the special circumstances. ${ }^{88}$

later, the Commander Sixth Division requested guidance from iifral Headquarters on the handling of reprisal claims. GHQ's of pretation of the Treasury policy is enlightening: "As any such int would be claims against the military, we should abstain from inting them and at the same time deny liability.... If persons wish

T/ 161/2/27246/Q, Treasury Ltr. of 20 May to War Office. 
to make claims, they should take legal advice from their solicitors and not from the persons whom they hope to make liable." 89

Correspondence in some of the previously cited claims files suggests that a few particularly meritorious cases were forwarded to the Joint Committee for payment, but there is no record of any having been paid. Only the minutes of the Committee's first meeting in August 1921 seem to have survived. The guidelines which they adopted are indicative of the policy they intended to follow:

"It was agreed that if poverty [of the elaimant] was to be allowed into consideration of claims no one would know where to draw the line. The argument that by refusing compensation in the cases of poor and loyal people that such action would drive them to disloyalty was answered by the argument that payment would not remedy this and that it was more likely that adherence to the principle "no payment" would bring home to every individual the evils of rebellion and create an anxiety to end it while in addition the aptitude of people to make dishonest or exorbitant claims is most noticeable among the very poor. ${ }^{90}$

Partition and the transfer of power to the Irish Free State occurred a few months later. In May 1922, the Compensation (Ireland) Commission was appointed by the two governments to handle the 40,000 propert damage claims outstanding, with instructions to "determine wha compensation ought in reason and fairness to be awarded in respect of destruction or injuries to property in Southern Ireland which woult either have been compensable by local authorities (as having been caused by criminal activities) or was the result of orders by militar authorities." 91 By 1926, when the program concluded, awards totallin six million pounds had been made. ${ }^{92}$ Although the British Government announced that "The contribution which has been made by this Commission towards healing the wounds created in 1920 and 1921 hat been a very great and valuable one," one member of the House of Lord described the announcement as "a real travesty of the facts." 93

89. WO 35169 , Ltr. GHQ 4-6-21, file 35/5491/1.

90. T/161/62/S.422.

91. Claims for personal injury were referred to a separate Commission. "Ment randum as to Compensation for Injuries to Persons and Property" (Cmd 194 1922). See also 56 HL Debs (ser 5) cols 1097-98 (26 March 1924) and "Reportc (Dunedin) Committee on Compensation for Persons who have suffered injury ... Ireland" (Cmd 2748, 1926).

92. The commission's work is described in Greer and Mitchell, Crimin Compensation, 16-18.

93. 61 HL Debs (ser 5) col 633 ( 17 June 1925). 


\section{Implications of the British Experience}

Whe British Army soon had the opportunities to apply the lessons med from their experiences in Ireland. Techniques of raid and inistal were honed in Mesopotamia and in Palestine before the Second Whar. After the war, they were applied in Cyprus, Malaya, and ira. Copied by the United States, Israel, and India, British tactics to be the basis for what has come to be known as "low intensity inge." 94 Although the Pentagon Library's selective bibliography of a a ture on this topic ${ }^{95}$ lists approximately three hundred items, a in of which relate to legal aspects of low intensity operations, none inem discuss the problems posed by claims that must necessarily when military force is used to suppress political violence. Since inger scholars nor practitioners of the art of low intensity warfare concerned themselves with the mundane problems of aggrieved gens, it is not surprising that U.S. Army manuals governing special arations ${ }^{96}$ are similarly silent. Arguably, in view of their expressed innitment to winning the hearts and minds of the civilian population,

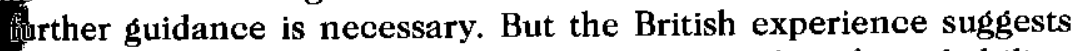
it if commanders are left to fashion their own rules of tort liability, sien rules will have little in common with peacetime notions of justice, he web of law will be irretrievably broken.

94. The term, originally synonymous with counterinsurgency, is derived from Gịter Frank Kitson's Low-Intensity Operations (Harrisburg, Pa.: Stackpole, Low Intensity Conflict (1985-1988) (Washington: Dept. of Army Library, Ther 1989).

96. FM 100-20, Low Intensity Conflict (HQ Dept of the Army, 16 January and FM 30-5, Combat Intelligence (HQ Dept of the Army, October 1973).

ajwing statement of ownership, management, and circulation was filed in accordance with ins of Section 4369, Title 39, U.S. Code, on 20 October 1992 by Larry I. Bland, Associate Journal of Military History is published quarterly by the Society for Military History, $\mathrm{c} / \mathrm{o}$ Dr. hivader, 910 Forbes Road, Carlisle, PA 17013. The Editor is Henry R. Bausum. The owner is Rifitary History, c/o Dr. Charles R. Shrader, 910 Forbes Road, Carlisle, PA 17013. There if

iro number of copies of each issue printed during the preceding twelve months was 2,619;

dealers and carriers, street vendors, and counter sales were 0 ; mail subseriptions to

ing subscribers were 2,328; total paid circulation was 2,328; free distribution was 50; total to 2,378 ; and 241 were for office use, leftover, or spoiled after printing. For the most recent i.j. 1992), total number of copies printed was 2,780; sales through dealers and carriers, wo and counter sales were 0 ; mail subseriptions to members and subscribers were 2,258 ; ilation was 2,258; free distribution was 50 ; total distribution was 2,308 ; and 472 were for intor, or spoiled after printing. 